Volume 7 Issue 1, March 2020

Nationally Accredited Journal,

Decree No. B/4130/E5/E5.2.1/2019

\title{
The Effects of Notary Code Breaking In Publication or Self Promotion in Pangkalan Bun
}

\author{
Ismi Hardiyanti ${ }^{1}$, Aris Sophian ${ }^{2}$ and Achmad Sulchan ${ }^{3}$ \\ Abstract. The purpose of this study was to: 1 ) to assess and analyze the legal \\ consequences for a notary public notary who violate the code of conduct in doing \\ publicity or self-promotion on the base bun. 2) to assess and analyze the \\ implementation of Effects Notary The Notary Code Breaking In Doing Publication Or \\ Self Promotion In Pangkalan Bun. \\ Based on the results of data analysis concluded that: 1) In the code of conduct notary \\ was clear in saying that a notary is prohibited from publishing or self-promotion, \\ either individually or jointly, it because may result in the authority and dignity of a \\ notary as a public official downhill , 2) Violation of Implementation notary who \\ violates the provisions of the code of conduct in the form of advertising self notary \\ was his only impact on the position of the Notary as a member of the Association and \\ no impact on the position of the notary as a public official. \\ Key words : Notary Code of Ethics; Self Promotion; Effects.
}

\section{Introduction}

Indonesia is a country of law as defined in Article 1 Paragraph 3 of the Constitution of 1945, meaning in the life of nation and state in Indonesia should be based on law, not the rule. The creation of legal certainty is one of the goals of the state law. Legal certainty is intended to provide protection for people in defending their rights. Ratification of the legally binding by the community conducted by the notary is also a form of the certainty of law.

Notary Public according to the legislation of the Republic of Indonesia Number 30 of 2004 on the office of the notary is an official General is authorized to make an authentic deed of all deeds, agreements, and provisions required by legislation and / or desired by the stakeholders to be stated in the deed authentic, guaranteeing the creation date of the deed, saving certificates, giving grosee, copy, and official copies, all of it throughout the making of the deed it not also be assigned or excluded to other officials or any other person specified by the Act.

Professions related to law are required to have a sense of sensitivity to the values of justice and truth and realize the legal certainty to the achievement and maintenance of public order. In addition, it is also obliged to always strive consciously virtuous to know all the rules of law that can be justified. Law and morality are equally related to human behavior, both equally regulate human behavior so that is always good and not falling prey that is not good.

Therefore a Notary in running the office of her should have responsibility for what was done it and are or behave based on Law Notary, Notary Code and Decree of the Minister of Justice and Human Rights of the Republic of Indonesia Number: M-01. HT.03.012003.

\footnotetext{
${ }^{1}$ Student Master of Notary Program Faculty of Law, Sultan Agung Islamic University Semarang, email ismihardiyantii@gmail.com

${ }^{2}$ Student of Master of Law Program, Faculty of Law, Universitas Islam Sultan Agung email arissophianelghi@gmail.com

${ }^{3}$ Lecturer of Faculty of Law, Sultan Agung Islamic University Semarang
} 
Since the issuance of the Decree of the Minister of Justice No.. M.05-HT.03.10 on "Notary Reform" which came into force on 26 June 1998, there was intense competition between the notaries who ultimately will affect competition among fellow Notaries. The regulation of notaries, one of which includes the determination formations notary office, appointment and transfer of notaries working area. Formation Notary is a rule for determining the amount of the required notary in a regency / city at the time they would be appointed as a notary. In addition Formation office also applies to the appointment and transfer of a notary.

With the advent of these rules then it is possible occurrence of unfair competition that occurs between the notary and also a violation of the law Position notary and also the code of conduct notary, as a result of imbalances in the formation in general and division of work areas or domicile in particular. To improve the marketing network in order to obtain a notary client may advertise itself through any media, including electronic and print media. It is actually against the limits that should not be violated by a notary, as set in Article 4 (3) of the code of conduct notary ban, which reads, Notaries and others (during the respective running notary office) are prohibited: Doing publicity or promotion themselves, either individually or jointly, by indicating the name and position, by means of print media and / or electronics, in the form of Advertising; Congratulations; Condolences; Acknowledgments; The marketing activities; Event sponsor, either in social, religious, and sports; And also to cooperate with the Bureau services / person / legal entity that essentially act as an intermediary to seek or obtain clients.

Based on the background mentioned above, the authors are interested in doing further research to be manifested in a research titled: "Effects Notary The Notary Code Breaking In publication Or Self Promotion In Pangkalan Bun". Who will discuss the legal consequences for violating a code of conduct Notary notary in publicizing or selfpromotion and implementation of its legal consequences for unethical notary notary in publicizing or self-promotion.

\section{Research methods}

The method used in this research is the socio-juridical, that in addition to using the principles and legal principles in reviewing, view, and analyze the problem, the research also review how its implementation in practice ${ }^{4}$, The use of sociological juridical approach is considered appropriate because, object or studied issues concerning the issues regulated normatively in law rules and regulations. This research uses descriptive analysis, the study was considered appropriate to analyze the problems being researched. The method that will be used to gather the data is by way of a field study (primary) and studies literature (secondary). Then the data was analyzed qualitatively to describe the results of the research, and the data will then be deduced deductively.

\section{Results and Discussion}

\subsection{Effects For A Notary The Notary Code Breaking In Doing Publication Or Self Promotion In Pangkalan Bun,}

\footnotetext{
${ }^{4}$ Rony Soekanto, 1984, Pengantar Penelitian Hukum, UI Press, Jakarta, p. 45
} 
Volume 7 Issue 1, March 2020

Nationally Accredited Journal,

Decree No. B/4130/E5/E5.2.1/2019

Notary is a state official or public officer appointed by the state to carry out the task the task of the state in legal services to the public in order to achieve legal certainty as authentic deed officials in the civil case.

Thus an notaris in running his office should have responsibility for what was done and the nature of his or behaves under Law Notary, Notary Code and Decree of the Minister of Justice and Human Rights of the Republic of Indonesia Number: M01.HT.03.01 Year 2003.

In carrying out his duties Notary shall be responsible to:

- God Almighty, in accordance with the oath or promise uttered by their respective religions, thus meaning something done Notaries in performing his respective duties will be accountable to God.

- State and society means that the state has given the confidence to run as a duty of the State in the field of civil law, namely in the manufacture of items of evidence in the form of a deed that has the strength of evidence was perfect, the people who have come to believe that a Notary be able to formulate his will in the form of notarial deed and believe that a Notary Public able to store (keep) any statement or speech given before a Notary ${ }^{5}$

In the code of conduct notary was clear in saying that a notary prohibited from publishing or self-promotion, either alone and together, it because may result in the authority and dignity of a notary as a public official declines. And also this ban has clearly set not only in a code of conduct notary but also in UUJN, following her description:

Code of Ethics

This violation of the code notary classified violated Articles as follows:

- Article 4, paragraph 3

"Notaries are prohibited from publishing or self-promotion options, either individually or together with the name and title, receipts means the print media and / or electronics, in the form of: a. Advertisement; b. Congratulations; c. Thank-you note; d. Marketing activities; e. Sponsorship activities, both in the social, religious, and sports. "

- Article 4, paragraph 4

"Notaries are prohibited from working with a service bureau / person / legal entity that essentially act as an intermediary to seek or obtain the client."

- Article 4, paragraph 15 letter a

"Notaries are prohibited Perform other actions are generally referred to as a violation of the Notary Code, including but not limited to violations: the provisions of Act No. 30 of 2004 concerning Notary."

- Article 6 of the Code of paragraphs 1 and 2

- The sanctions may be imposed against members who violate the Code of Conduct can be: strikes; Warning; schorsing (temporary dismissal) of the Association membership; onzetting (dismissal) of the membership of the Association; dishonorable discharge from membership society.

- The imposition of sanctions - as described above sanctions against members who violate the Code of Conduct adapted to the quantity and quality of the violations committed by members.

${ }^{5}$ Habib Ajie, 2007, Hukum Notaris Indonesia (Tafsir Tematik Terhadap Undang-undang Nomor 30 tahun 2004 tentang Jabatan Notaris), PT. Revika Aditama, Surabaya, p.13 
Its light weight or sanction given to the notary depends on its small major violations committed by a notary public in the then than it would be determined whether he will be subjected to disciplinary, civil or criminal sanctions.

While in UUJN considered in violation of the following articles:

Article 1 (1):

"Notary is a public official authorized to make an authentic deed and other authorities referred to in this Act."

The position of a notary as a public official is an honorable positions given by the State attributive through Law to someone they trust. But the lifting of a notary is to the Minister, under Article 2 of Law Notary, then it should Notary should not be doing activities - activities that aim to benefit himself.

Article 2 UUJN

"Notaries are appointed and dismissed by the Minister"

Because it was raised by the minister this is the result that the Notary shall safeguard the prestige and dignity of the position.

Therefore it relates to:

Article 85 UUJN:

"Violation of the provisions referred to in Article 7, Article 16 paragraph (1) letter a, Article 16 paragraph (1). B, Article 16 paragraph (1) C, Article 16 paragraph (1) letter d, Article 16 paragraph (1) letter e, Article 16 paragraph (1) letter f, Article 16 paragraph (1) letter $g$, Article 16 paragraph (1) letter $h$, Article 16 paragraph (1) letter I, Article 16 paragraph (1) letter j, Article 16 paragraph (1) letter k, Article 17, Article 20, Article 27, Article 32, Article 37, Article 54, Article 58, Article 59 and / or Article 63, may be subject to the following sanctions: verbal warning; written warning; layoffs; honorable discharge; or dishonorable discharge.

\subsection{Implementation Effects Notary The Notary Code Breaking In Doing Publication Or Self Promotion In Pangkalan Bun}

Indonesian Notary Association as Professional organizations can impose sanctions against the notary who violates the code of conduct, in an effort to maintain the honor and dignity of office notaries, notary THIS adopt codes of conduct established by the Congress and the moral rules that must be obeyed by every member of INI. Honor Council is the organ competent IT equipment to conduct examination of a violation of the code of conduct and sanctions against violators in accordance with the authority ${ }^{6}$ and is responsible for:

- Conducting coaching, guidance, supervision, reform member of upholding the code of conduct.

- Examine and make decisions on alleged breach provisions of code of conduct that is internal or who do not have the public participates directly.

- Provide advice and opinion to the supervisory council of the alleged violations of ethics codes and notary office.

This Regional Board has the Honor Council of Regions on any of stewardship. Honorary council area consists of three (3) members among them, a chairman, a deputy chairman and a secretary. Which can be appointed a member of the Honorary Board of the Regional is a regular member who has served as a notary at least five (5) years and a member outstanding (former notary), who always obey the rules of clubs and

\footnotetext{
${ }^{6}$ Anggaran Dasar Ikatan Notaris Indonesia, results of the Extraordinary Congress of Bandung on January 27, 2005.
} 
Volume 7 Issue 1, March 2020

Nationally Accredited Journal,

Decree No. B/4130/E5/E5.2.1/2019

the legislation in force, dedicated, meritorious and loyal and have a sense of high concern to the association ${ }^{7}$

Country honorary council can look for the fact of infringement on their own initiative or after receiving a complaint in writing from a person's member associations or others with evidence that convinced that there has been a violation of the code etilk, after finding the facts of violations of the code of ethics or after receiving the complaint, shall call members concerned to ascertain whether it really has been a violation and provide an opportunity to provide an explanation and defense.

For notary who violates the code of conduct relating to the promotion of self then, the honorary coordinate with the supervisory council authorized to conduct examination of these violations and to impose sanctions on violators, sanctions imposed upon members of the Indonesian Notary Association who violates the code of conduct can be $^{8}$ : warning; Warning; Schorzing (layoffs) from the membership of the Association; Onzetting (dismissal) of the Association membership; Dishonorable discharge from membership Society.

The sanctions of dismissal given to the notary who violates the code of conduct in the form of self-promotion is not a form of dismissal from the office of a notary, but the dismissal of membership Indonesian Notary Association, so that even though the notary concerned has proved to have violated the code of conduct, the notary will be able to exercise its authority as a public official. Because only the appropriate ministries to dismiss a notary from office by listening to the report of the Supervisory Council, so that these penalties do not seem to have a big impactagainst notaries as public officials who violate the code of ethics.

\section{Closing}

\subsection{Conclusion}

Based on the research results can be in Tarik conclusion following:

- In the code of conduct notary was clear in saying that a notary in banned from publishing or self-promotion, either individually or jointly, it may result in the authority and dignity of a notary as a public official declines. It has been clearly stated in the code of conduct notary on the article:

Article 4 paragraph 3 and 4, Article 4, paragraph 15 (a), Article 6, paragraph 1 and 2. And also UUJN the article: Article 1, paragraph 1, article 2 UUJN, and also concerning Article 85 UUJN.

- Violation of Implementation notary who violates the provisions of the code of conduct in the form of an advertiser's notary himself was his only impact on the position of the Notary as a member of the Association and no impact on the position of the notary as a public official.

So even though the notary concerned has proved to have violated the code of conduct, the notary can still make a deed and execute other authorities as a public official, so that these penalties not only seem less have binding power, but even as it did not affect the notary who violates the code of conduct.

\footnotetext{
${ }^{7}$ ibid

${ }^{8}$ Single Setia Hadi, 2006, Peraturan Pelaksanaan Undang-undang jabatan Notaris, Harvarindo, Jakarta, p. 306.
} 
eISSN : 2581-2114, pISSN: 2406-9426

\subsection{Suggestion}

- Notary in running his office must be in accordance with the code of conduct notary and also UUJN, because the notary is a public official function to serve the community. And also in the running of chair due a notary does not expect the benefits of its profusely, and therefore prohibited from performing notarial act aimed for profit including services market.

- To give greater emphasis to the sanction given to the notary who has violated the code of conduct in the form of marketing or advertiser's self, the necessary firmness and supervision of the board honorary notary against sanctions, in order to really binding and followed by the abuse, also needs to be a procedural law against violations of the code of conduct notary who can provide protection and assurances as to the public interest

\section{References}

[1] Results of the Extraordinary Congress, 27 January 2005, Anggaran Dasar Ikatan Notaris Indonesia, Bandung.

[2] Habib Ajie, 2007, Hukum Notaris Indonesia (Tafsir Tematik Terhadap Undangundang Nomor 30 tahun 2004 tentang Jabatan Notaris), PT. Revika Aditama, Surabaya.

[3] Hadi Setia Tunggal, 2006, Peraturan Pelaksanaan Undang-undang Jabatan Notaris, Harvarindo, Jakarta.

[4] Rony Soekanto, 1984, Pengantar Penelitian Hukum, UI Press, Jakarta.

[5] Law of the Republic of Indonesia No. 30 of 2004, Article 1, paragraph 1, article 2, and article 85 on the Notary Office.

[6] Law Notary Code Article 4 (3) and 4, Article 4, paragraph 15 (a), Article 6, paragraph 1 and 2.

[7] Decree of the Minister of Justice of the Republic of Indonesia Number. M.05HT.03.10 about a Notary Reform 